 \\ International Journal of Social Sciences and Management
}

\section{A Rapid Publishing Journal}

ISSN 2091-2986

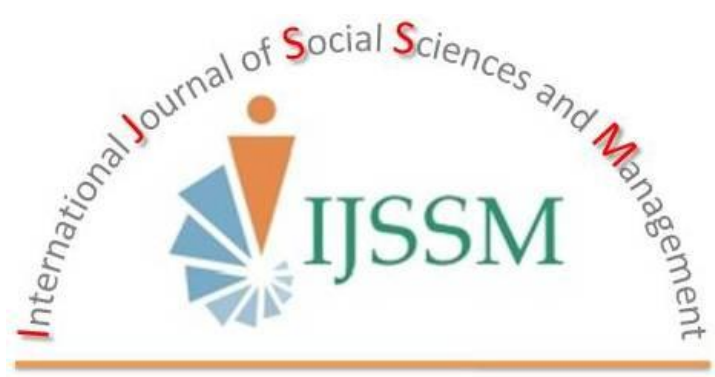

\section{Indexing and Abstracting}

CrossRef, Google Scholar, International Society of Universal Research in Sciences (EyeSource), Journal TOCs, New Jour, Scientific Indexing Services, InfoBase Index, Open Academic Journals Index (OAJI), Scholarsteer, Jour Informatics, Directory of Research Journals Indexing (DRJI), International Society for Research Activity (ISRA): Journal Impact Factor (JIF), Simon Fraser University Library, etc.

Vol-2(2) April, 2015

SEM-Biotech

Publishing

Impact factor ${ }^{*}: \mathbf{3 . 3 8 9}$ 


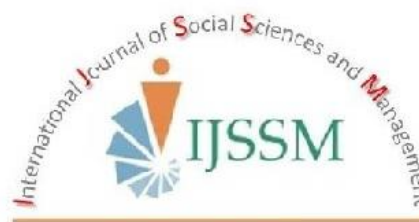

\title{
International Journal of Social Sciences and Management
}

\section{Research Article}

\section{SCALE-UP POTENTIALITIES OF SOME SOCIAL SAFETY NET PROGRAMMES TO CLIMATE CHANGE SHOCKS IN BANGLADESH}

\author{
M.A. Awal \\ Laboratory of Plant Ecology, Department of Crop Botany, Bangladesh Agricultural University, Mymensingh 2202, Bangladesh
}

Email: awalma7@yahoo.com

\begin{abstract}
Although Bangladesh is quite advanced in terms of setting up systems of social safety net (SSN) but the services in dealing climate change has gained little attention. On the other hand some specific public SSN programmes (SSNPs) like Vulnerable Group Development (VGD), FoodFor-Work (FFW), Rural Employment and Road Maintenance Programme (RERMP) and Chars Livelihood Programme (CLP) through which most distressed and right less poor especially vulnerable rural women are benefitted, not yet tested whether the programmes promoted as climate proofed. Therefore the study was conducted for adapting those four SSNPs in dealing with climate change shocks like cyclone, flood, drought, water logging and salinity for escaping climate vulnerable poor from chronic poverty. Quantitative analysis has been made using the Household Income and Expenditure Survey (HIES) 2010 data set. Focus Group Discussion (FGD), Participatory Rural Appraisal (PRA) session and Case Studies were performed for addressing current SSNPs with their weaknesses or effectiveness and scale up potentialities to explore better livelihood and food security options for climate poor. Relevant stakeholders in government and NGO programmes have been consulted to assess the feasibility of options for further strengthening of aforesaid SSNPs. It is found that the SSN intervention with VGD, FFW and RERMP have minimum scope in dealing with climate change although the said tools are important especially to disadvantaged rural women for creating their employment opportunity as well as poverty alleviation. The VGD beneficiaries can properly be engaged to sustainable income generation and microfinance activities for future saving to promote adaptive capacity which would enhance their resiliencies to cope with climate change. The dead or silted-up rivers, canals or ponds and irrigation channels can be excavated or re-excavated by operating the major workfare SSNPs like FFW and the excavated soil can be utilized for creating, maintaining or elevating rural roads, embankment and other infrastructures which are quite crucial for mitigating the flood, storm surge, water logging or salinity issues. The canals or ponds can additionally be utilized for enough harvesting of monsoon rain or flood water thus salinity and drought problems would be minimized for a better agricultural intervention in the affected areas. The RERMP beneficiaries can be engaged to maintain embankments and tree plantation at pond periphery or at barren land with their proper nursing, compost preparation etc. The CLP is found as a concrete example for achieving climate change adaptation to uplift the socio-economic status of chronic poor char dwellers to recurrent floods in Jamuna and Brahmaputra basins. This programme can be extended from an 18-month to a two-year period and should have to spread-up to the chars of other vulnerable flood prone areas of Bangladesh. A good agricultural marketing system is also essential for proper and timely marketing of CLP-products in the locality.
\end{abstract}

Key words: Chars Livelihood Programme; Food-for-Work; Rural Employment and Road Maintenance Programme; Social Safety Net; Vulnerable Group Development.

\section{Introduction}

Social safety nets (SSNs) or socioeconomic safety nets are non-contributory transfer programmes seeking to prevent the poverty or those vulnerable to shocks. On the other hand, the safety net services not only use to help people during sudden disaster but can also contribute to long-range development of a community. The scope of the definition of SSN varies considerably across international organizations and scholars. For example, in Poverty Reduction Strategy Paper (PRSP), the SSN is defined as actions, policies and programs that attempt to reduce poverty through direct transfer of resources to the poor. In an ESCAP study, Jurado (2001) stated that SSNs are programs intended to assist people who have been adversely affected by shocks and other kinds of emergencies, not necessarily the poor. SSN works in conjunction with a number of other poverty reduction programs with the primary goal of reducing or preventing poverty. The SSN programs can be classified into formal and informal safety nets that are generally, distinguished by law enforcement or legal support of the assistance. The formal safety nets are those which legally guarantee individuals access to economic or social support whereas informal safety nets provide likelihood of support to individuals to assure them of attaining or remaining above the designated minimum standard of living but with no legal guarantee. Furthermore, informal SSNs can be divided into private for example 
transfers from family members, friends, neighbors, charities, and community members and institutions, including NGOs or private firms; or public which refers to the support that individuals expect from the government or state and aid donors, through programs which generate assets or employment, transfer income, or provide basic social services, as a means of helping affected individuals from falling below the designated minimum standard of living (Paitoonpong et al., 2008).

During independence of Bangladesh in 1971 when $70 \%$ of the population lived below the poverty line, only two programs e.g. food rations and relief works were considered as SSN tools for supporting the hungers as well as disaster victims. With time elapsed the government has widespread the safety net supports for the poor. At present Bangladesh has more than hundred public SSNPs like Vulnerable Group Development (VGD), Old Age Allowance (OAA), Widowed or Distressed Women Allowance and Disability Allowance, Vulnerable Group Feeding (VGF), Food-forWork (FFW), Cash-for-Work (CFW), Test Relief (TR), Gratuitous Relief (GR), 100 Days Employment Support etc (BDS, 2006). At least 13 ministries are engaged in the planning and implementation of those programmes. Currently $25 \%$ of the households are benefitting from one of many SSNPs which are administered by a large number of agencies and ministries (HIES, 2010).

In Bangladesh, most of the SSNPs rely on food aid; some of those transfer cash whereas some provide a combination of both. Some of those SSNPs are conditional while most of the programmes are unconditional (Morshed, 2009). The contribution of the currently operating SSNPs for mitigating the climate shocks is insufficient in Bangladesh. Most of the initiatives are 'ex post' coping initiatives, with a few being 'ex ante' preventive measures that represent a poor SSN policy in the country. For providing SSN aid a location is targeted based on the occurrence of disaster or calamity. Only a few SSNPs such as TR, VGF, GR etc are using in small scale to mitigate the sufferings of people who are affected by natural disasters (BDS, 2006).

By providing immediate access to food, safety nets have an important role to play in enabling poor households to sustainably deal with the shorter-term impacts of climate change. On the other hand, there is also growing evidence that SSN can play a critical role in reducing the immediate impact of climate change, and in the longer run, strengthen the resilience and adaptive capacity of people to climate change impacts (Béné, 2011). By combining their activities with other interventions such as income generation activities, distribution of saline resistant seed varieties (act as climate change adaptation, CCA) and disaster preparedness trainings (i.e. disaster risk management, DRM), SSNs may also allow households to invest in adapting and/or protecting their livelihood strategies. This, in turn, will reduce their exposure and increase their resilience to climate change-related shocks. There is a growing recognition that social protection or SSN programme needs to become 'climate proofed' if social protection interventions are to remain effective in the long term. 'Climate-proofing' as actions that make systems more resilient and resistant to hazards associated with climate variability and extremes, as well as geological hazards (UNDP, 2010). Social protection policymakers and practitioners cannot afford to ignore climate change any longer and need to integrate this new constraint into their planning and action plans. A good integration from any service like SSN operation may be achieved when the benefits from DRM and CCA are integrated together (Awal, 2013). However, little information is available to policymakers at present on how SSN intervention integrates to DRM and CCA in Bangladesh.

Bangladesh is quite advanced in terms of setting up systems of SSNs, but they are not always reliable or as prepared for disasters as might be expected. How are SSNs moving from reacting to disasters/emergencies to predicable SSNs on which the poor can rely to address their different climate related risks? Therefore, the present study is designed to layout options for strengthening the effectiveness of some existing Bangladeshi safety nets such as VGD, FFW, RERMP and CLP in dealing with climate change related shocks such as floods, cyclones, water logging, salinity and drought, taking into account administrative and operational capacity and institutional set-up.

\section{Materials and Methods}

The study comprised both the secondary and the primary sources of data. The secondary data mainly on social safety net information that were collected from publicly accessible Household Income and Expenditure Survey (HIES) 2010 dataset. Most of the results comprised with primary data that were collected through stakeholder consultation and other qualitative approach and survey tools like Focus Group Discussion (FGD), Participatory Rural Appraisal (PRA) session and Case Studies. The rural poor especially disadvantaged women throughout Bangladesh are mostly benefitted with some specialized SSN devices like Vulnerable Group Development (VGD), Rural Employment and Road Maintenance Programme (RERMP), Food-for-Work (FFW) and Chars Livelihood Programme (CLP) (details in Appendices I-IV). Therefore the aim of this study is to layout some options for strengthening the effectiveness of those safety net programmes in dealing with some common climate change related shocks such as floods, cyclones, water logging, salinity and drought in socioeconomic conditions of Bangladesh.

\section{Stakeholder consultation}

The major stakeholders were identified based on the services they are providing (service providers i.e. official stakeholders) and what services they are receiving (service users i.e. affected people) from all kind of climate shock 
areas like flood, cyclone, water logging, salinity and drought. The official stakeholders concerned to safety net and other service provider's especially related to agricultural production like crops, livestock, fisheries etc and disaster management and water development were consulted (Table 1; Fig. 1). Therefore the consultations with those stakeholders at local and central level officials from Ministry of Disaster Management and Relief (MoDMR), Ministry of Agriculture (MoA), Ministry of Environment and Forests (MoEF), Ministry of Fisheries and Livestock (MoFL), Ministry of Water Resources (MoWR), and Ministry of Local Government, Rural Development and Cooperatives (MoLGRDC) as well as NGO programme staffs of Grameen Bank, BRAC, PROSHIKA, ASA, WFP, Jagoroni Chakra Foundation, Shushilon etc were conducted to understand the type of services they are providing to the disadvantaged or vulnerable households under climate shocks areas. The consultation of GO and NGO officials were done with institutional managers. The government officials and NGO program staffs were contacted prior to the consultation by electronic mail or telephone explaining the objectives of the consultation.

\section{Qualitative approach and survey tools}

The views of the affected villagers/service users corresponding to climate shock events like flood, cyclone, water logging, salinity and drought areas were collected through qualitative approaches or tools using Focus Group Discussion (FGD), Case Studies, and Participatory Rural Appraisal (PRA) sessions (Table 2; Fig. 2).
Initially the affected areas for primary data collection were selected by climate and poverty maps (BBS-WB-WFP, 2009; WFP, 2014; http://www.dmb.gov.bd/gis.html). Thereafter more specific survey areas were selected with the consultation with DAE's officials like Deputy Director (DD), Upazila Agriculture Officer (UAO), Upazila Extension Officer (UEO) etc. The service users were selected randomly from affected poor villagers and accumulated with the help of the local administrative personnel like Sub Assistant Agriculture Officer (SAAO), Union Council Chairman, Union Councilor (formerly known as Ward Member) or other Local Leaders.

The FGDs were conducted with two phases. The first phase FGDs with affected villagers distributed to all seven administrative divisions of Bangladesh covering several types of climate change shocks (Table 1) were conducted to collect their views and opinions about the services they are receiving from various GO and NGOs. During primary data collection the villagers were asked to indicate the existing SSNs and their effectiveness, and whether these SSN tools are enough to address their food security problems or to what extent the programmes should be modified or scaled up to reach the actually vulnerable households to cope or mitigate the climatic shocks for achieving CCA. People's views/opinions whether they think any other alternative safeguards or social protection measures to increase their resiliencies as well as rural development against more frequent climate-related shocks were also considered.

Table 1: Service providers/stakeholders of some specific SSNPs and other interventions at different levels ${ }^{\mathrm{a}}$

\begin{tabular}{|l|l|l|l|l|l|}
\hline $\begin{array}{l}\text { SSNP and } \\
\text { other } \\
\text { intervention }\end{array}$ & Ministry & $\begin{array}{l}\text { Department/ } \\
\text { Officer }\end{array}$ & $\begin{array}{l}\text { Implementing } \\
\text { Officer at District } \\
\text { level }\end{array}$ & $\begin{array}{l}\text { Implementing } \\
\text { Officers at Upazila } \\
\text { level }\end{array}$ & $\begin{array}{l}\text { Implementing } \\
\text { Officers at } \\
\text { Union level }\end{array}$ \\
\hline VGD & $\begin{array}{l}\text { Ministry of Women } \\
\text { and Children Affairs }\end{array}$ & $\begin{array}{l}\text { Department of Women } \\
\text { Affairs Office (DWA)/DG }\end{array}$ & $\begin{array}{l}\text { District Women } \\
\text { Affairs Officer }\end{array}$ & $\begin{array}{l}\text { Upazila Women } \\
\text { Affairs Officer }\end{array}$ & $\begin{array}{l}\text { Union Council } \\
\text { Chairman }\end{array}$ \\
\hline RERMP & MoLGRDC & LGED/ Project Director & Executive Engineer & $\begin{array}{l}\text { Upazila LGED } \\
\text { Engineer }\end{array}$ & - \\
\hline \multirow{2}{*}{ FFW } & MoDMR & $\begin{array}{l}\text { Department of Disaster } \\
\text { Management/ Director } \\
\text { General (DG) }\end{array}$ & $\begin{array}{l}\text { District Relief and } \\
\text { Rehabilitation } \\
\text { Officer (DRRO) }\end{array}$ & $\begin{array}{l}\text { Project Implemention } \\
\text { Officer (PIO) }\end{array}$ & $\begin{array}{l}\text { Union Council } \\
\text { Chairman }\end{array}$ \\
\hline CLP & MoLGRDC & $\begin{array}{l}\text { HQ at Rural Development Academy (RDA), Bogra/ } \\
\text { Programme Coordinator }\end{array}$ & $\begin{array}{l}\text { Upazila Coordinator (GoB), } \\
\text { Local NGOs like BRAC, RDRS etc. }\end{array}$ \\
\hline \multirow{2}{*}{$\begin{array}{l}\text { Agricultural } \\
\text { intervention }\end{array}$} & MoA & $\begin{array}{l}\text { Department of Agriculture } \\
\text { Extension (DAE) }\end{array}$ & $\begin{array}{l}\text { Deputy Director } \\
\text { (DD) }\end{array}$ & $\begin{array}{l}\text { Upazila Agriculture/ } \\
\text { Extension Officer }\end{array}$ & $\begin{array}{l}\text { Sub-Assistant } \\
\text { Agriculture } \\
\text { Officer }\end{array}$ \\
\cline { 2 - 6 } & MoFL & $\begin{array}{l}\text { Department of Livestock/ } \\
\text { Fisheries }\end{array}$ & $\begin{array}{l}\text { District Fisheries/ } \\
\text { Livestock Officer }\end{array}$ & $\begin{array}{l}\text { Upazila Fisheries/ } \\
\text { Livestock Officer }\end{array}$ & - \\
\hline CDMP & MoDMR & National Project Director & DAE personnel & & $\begin{array}{l}\text { Executive Engineer, Flood } \\
\text { Forecasting and warning } \\
\text { Centre (FFWC) }\end{array}$ \\
\hline $\begin{array}{l}\text { Water } \\
\text { Management }\end{array}$ & MoWR & (BWDB) & \\
\hline
\end{tabular}

${ }^{a}$ Refer to Appendix $\mathrm{V}$ for local terms.

${ }^{b}$ Officials of Barind Multipurpose Development Authority (BMDA) have also been consulted.

LGED: Local Government Engineering Department; CDMP: Comprehensive Disaster Management Programme. 


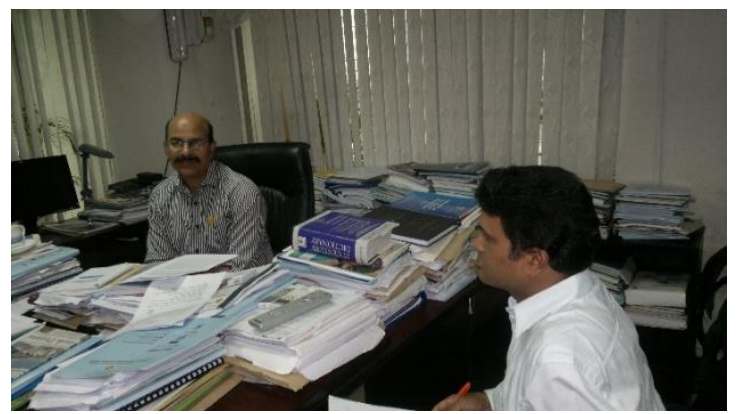

Mr. Mohammad Abdul Qayum, National Porject Director, Comprehensive Disaster Managemnet Programme (CDMP), Ministry of Disaster Management and Relief, Mohakhali, Dhaka on November 4, 2012.

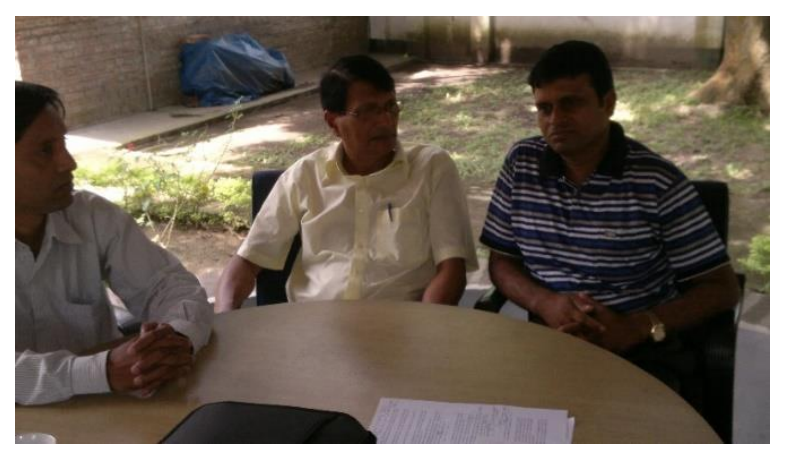

Dr. Md. Mahbub Alam, Livelihoood Coordinator, and Mr. Md. Nozrul Islam, Horticulture Coordinator, CLP, Rural Developemnt Academy (RDA) Campus, Sherpur, Bogra-5842 on September 19, 2012.

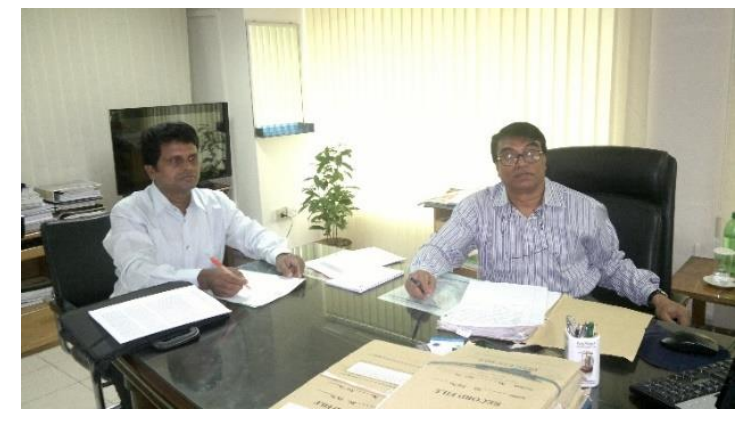

Mr. Mohammad Abdul Wazed, Additional Secretary and Director General (DG), Department of Disaster Management (DDM), Ministry of Disaster Management and Relief, Mohakhali, Dhaka on November 4, 2012.

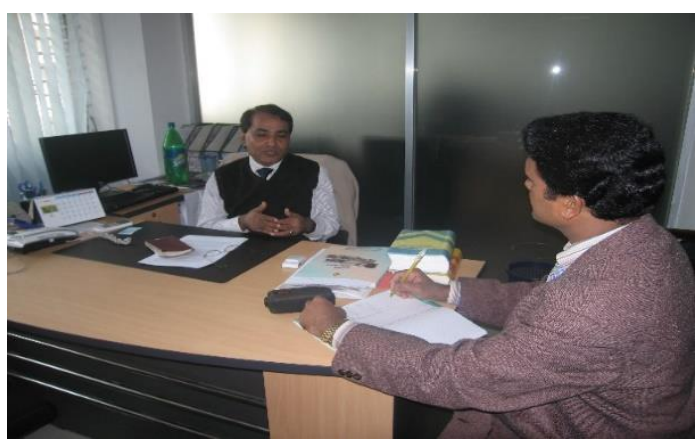

Mr. Nurul Islam Talukder, Additional Director, VGD Programme, Departmnet of Women Affairs, Ministry of Women and Children affairs, GoB, 37/3 Eskaton Garden Road, Ramna, Dhaka-1000 on January 30, 2013.

Fig. 1: Photographs show consultation with some stakeholders working at various institutes of Bangladesh.

Table 2: Sites $^{\mathrm{a}}$ visited for qualitative collection of data by FGD, PRA and Case studies

\begin{tabular}{|c|c|c|}
\hline Category of climatic shocks & Address & Survey tools used \\
\hline \multirow{2}{*}{$\begin{array}{l}\text { Cyclone + Flood+ Water } \\
\text { logging + Salinity }\end{array}$} & Village-Shibpur, Union-Tala Sadar, Upazila-Tala, Satkhira & PRA session \\
\hline & Village-Nowapara, Union-Tetulia, Upazila-Tala, Satkhira & FGD, Case study \\
\hline $\begin{array}{l}\text { Cyclone }+ \text { Water logging }+ \\
\text { Salinity }\end{array}$ & $\begin{array}{l}\text { Village-Nachunia, Union-Sachiadah, Upazila-Terokhada, District- } \\
\text { Khulna }\end{array}$ & FGD, Case study \\
\hline \multirow{3}{*}{ Cyclone + Salinity } & $\begin{array}{l}\text { Village-Sankarkathi, Union-Kashimari, Upazila-Shayamnagar, } \\
\text { Satkhira }\end{array}$ & Case study \\
\hline & Villagers from Union-Atulia, Upazila-Shyamnagar, Satkhira & PRA, Case study \\
\hline & $\begin{array}{l}\text { Village-East Razoire, Union-Khontakata, Upazila-Soronkhola, } \\
\text { Bagerhat }\end{array}$ & FGD, Case study \\
\hline $\begin{array}{l}\text { Water logging + Flood + } \\
\text { Salinity }\end{array}$ & $\begin{array}{l}\text { Village- Santana/Kalicharanpur (Bhabodoh water logged area), Union- } \\
\text { Shufolakathi, Upazila-Keshabpur, Jessore }\end{array}$ & FGD, Case study \\
\hline \multirow{4}{*}{$\begin{array}{l}\text { Flash flood/flood + River bank } \\
\text { erosion }\end{array}$} & $\begin{array}{l}\text { Village-Raumari Uttar Para, Ward No. 1, Union-Raumari Sadar, } \\
\text { Upazila-Raumari, Kurigram }\end{array}$ & FGD, Case studies \\
\hline & $\begin{array}{l}\text { Village-Chardhantola, Union-Datbhanga, Upazila- Raumari, District- } \\
\text { Kurigram }\end{array}$ & FGD, Case studies \\
\hline & $\begin{array}{l}\text { Village-Izlamari, Union-Raumari Sadar, Upazila- Raumari, District- } \\
\text { Kurigram }\end{array}$ & FGD, Case study \\
\hline & $\begin{array}{l}\text { Village-Isakuri Moddha Para, Union-Raumari Sadar, Raumari, } \\
\text { Kurigram }\end{array}$ & FGD, Case study \\
\hline \multirow{2}{*}{ Flood + River bank erosion } & Village-Dhiapar, Union- Chala, Harirampur, Manikganj & Case study \\
\hline & Some villagers from Boyra Union, Upazila-Harirampur, Manikganj & FGD \\
\hline Cyclone + tidal flood + Salinity & $\begin{array}{l}\text { Village-Bashunia and Kalai Kishoor, Union- Amkhola, Upazila- } \\
\text { Golachipa, District- Patuakhali }\end{array}$ & FGD, PRA, Case study \\
\hline Flash flood/flood & $\begin{array}{l}\text { Village-Sonaru and Bhatipara, Union- Subidpur, Upazila- } \\
\text { Baniyachang, District- Habiganj }\end{array}$ & FGD, PRA, Case study \\
\hline Cyclone + flash/ hilly flood & $\begin{array}{l}\text { Village-Lamba Gona, Union- Choto Maheshkhali, Upazila- } \\
\text { Maheshkhali, District- Cox’s Bazar }\end{array}$ & FGD, PRA, Case study \\
\hline Drought & $\begin{array}{l}\text { Village- Shibpur Shiala, Mattapur and Brahman Para, Union- Nachole } \\
\text { Sadar, Upazila- Nachole, District-Chapai Nawabganj }\end{array}$ & FGD, PRA, Case study \\
\hline
\end{tabular}

${ }^{\mathrm{a}}$ Refer to Appendix V for local terms. 


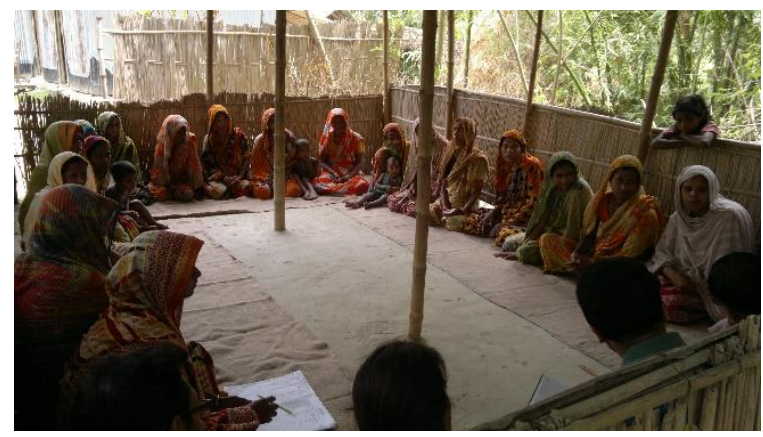

Some CLP participants in flood and river bank erosion prone char at Raumari, Kurigram district on May 16, 2012.

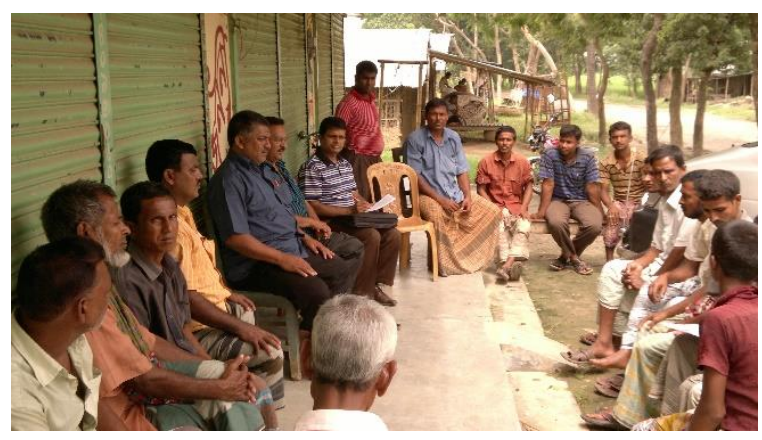

Drought affected rural villagers at Nachole, Chapai Nawabganj district on September 20, 2012.

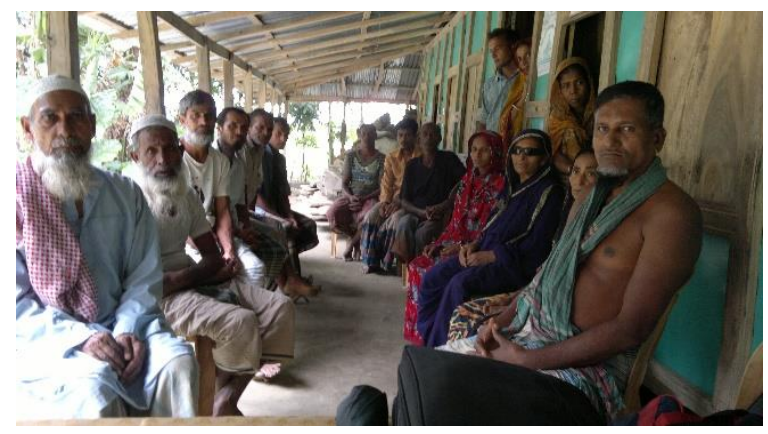

Cyclone/storm and salinity affected rural villagers at Golachpa, Patualkhali district on July 28, 2012.

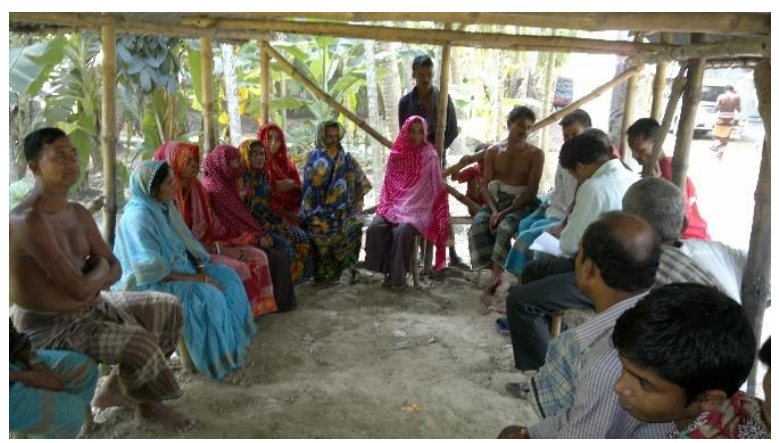

Water logged affected rural villagers at Terokhada, Khulna district on November 13, 2012.

Fig. 2: Photographs show some FGDs with climate-stressed rural villagers in different regions of Bangladesh.

\section{Results}

\section{Quantitative analyses}

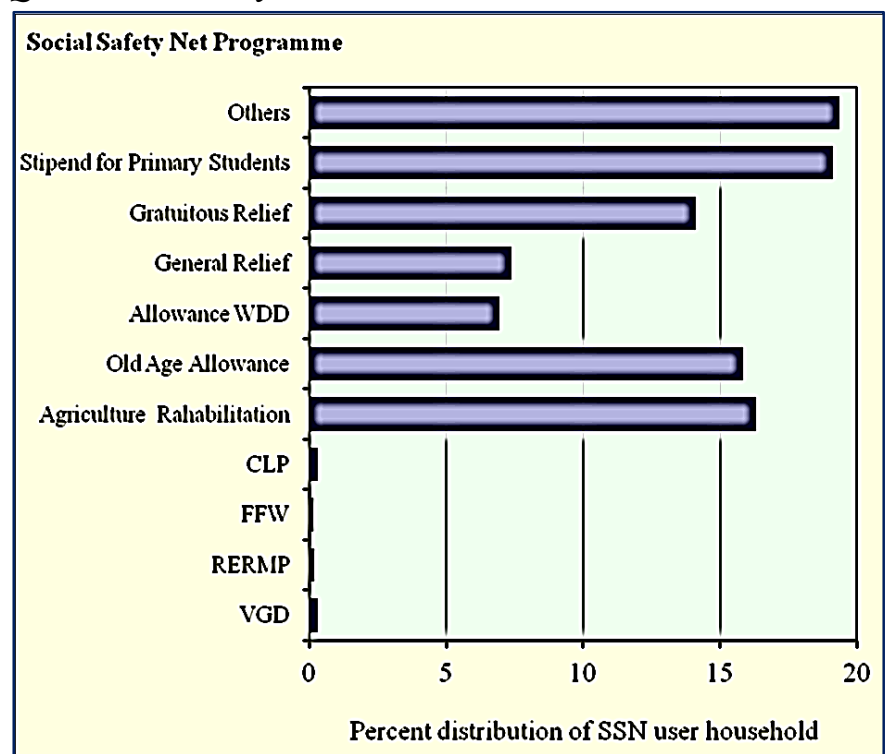

Fig. 3: Distribution of social safety net users by types of programme (HIES, 2010).

Among the thirty social safety net programmes as mentioned in HIES 2010, the percentage of beneficiary households from four targeted programmes in this study like VGD, RERMP, FFW and CLP was found very minimum as compared to the proportion of beneficiary household in the remaining programmes (Fig. 3). These four programmes in-combined covered only less than a percent beneficiary households throughout Bangladesh. Even there were a lot of non-poor SSN users in these four programmes where inclusion of non-poor household was at least 40 percent (Fig. 4).

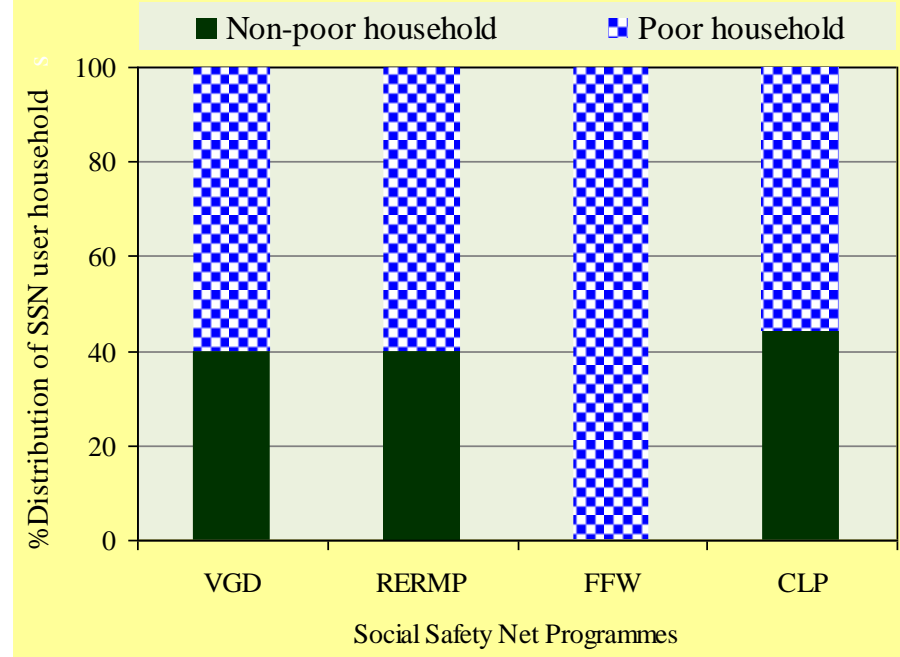

Fig. 4: Distribution of VGD, RERMP, FFW and CLP users within poor and non-poor households throughout rural Bangladesh (HIES, 2010). 


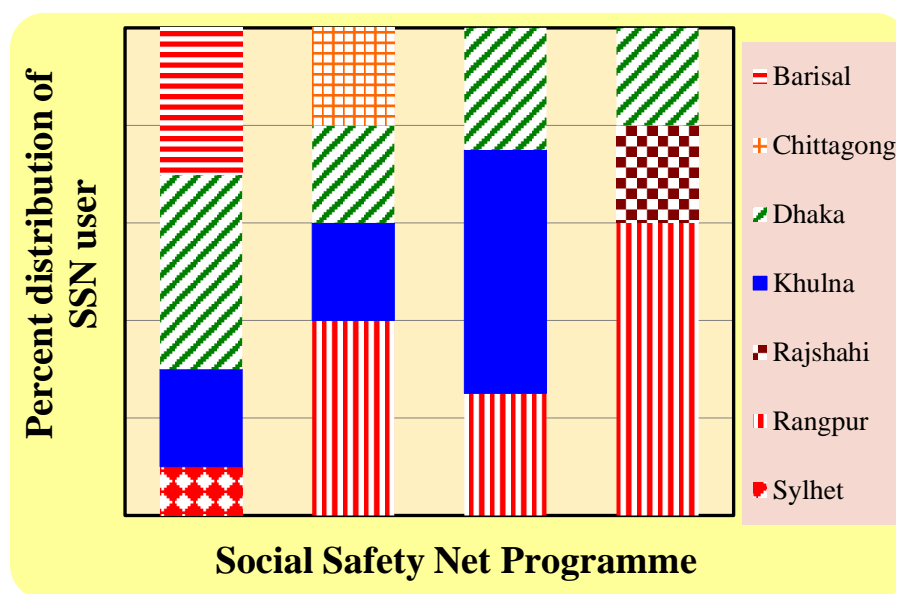

Fig. 5: Distribution of VGD, RERMP, FFW and CLP users by administrative division (HIES, 2010).

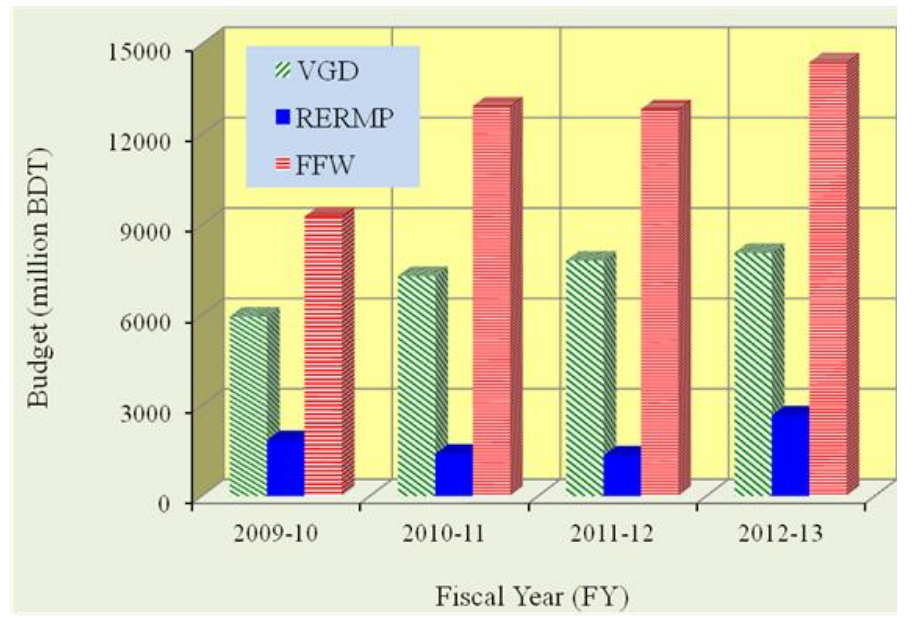

Fig. 6: Budget of VGD, RERMP and FFW programmes.

[Source: Budget Document, Ministry of Finance, Government of the People's Republic of Bangladesh.]

\section{Qualitative analyses: climate proofing of safety net interventions}

The study is especially concerned to address the effectiveness and scale up potentialities of some common Bangladeshi safety net programmes like Vulnerable Group Development (VGD), Food-for-Work (FFW), Rural Employment and Road Maintenance Program (RERMP), and Chars Livelihood Porgramme (CLP) in dealing with climate change shocks for example flood, cyclone, water logging, salinity and drought. The major objectives, selection criteria, nature of benefits of those programmes are briefly mentioned in Appendices I-IV. The findings obtained from qualitative tools like stakeholder consultation and field survey are presented.

\section{Vulnerable Group Development (VGD)}

The VGD helps distressed, widowed, divorced women or women with disable husband. Thus the programme contributes a lot to uplift the livelihood status of those types of vulnerable households. The results obtained from the FGDs, case studies and PRA sessions as well as consultation to concerned stakeholders and HIES datasets suggests that as a safety net programme, VGD is playing an important role for promoting the food security to the most vulnerable households where husband have either been died or disabled. It is a good initiative of the GoB for eradicating malnutrition from the right less, frustrated and deprived, and guardian less female headed households throughout the country (Fig. 7).

It is playing an important role for removing food insecurity whether the benefitted households are affected by climate shocks or not as it is a nationwide programme which did not think the climate change any more. However, the programme can also reduce the disaster risk traditionally if the benefitted households are affected by any kind of extreme weather.

Although the programme provides a good opportunity to the beneficiary to engage them to alternative income generation activities through promoting their skills for future savings but most of the households cannot take such privilege rather they pass the time as hand to mouth. Consequently they become food-insecure further following the termination from the programme. Hence the current operational structure of VGD programme cannot promote the livelihood status substantially to shift them to a safer place where CCA needs additional promotion. To turn VGD programme as 'climate proofed' the DRM components should always be worked even after graduation of household from the programme. Sustainable income generation and microfinance activities can play decisive role for promoting adaptive capacity through necessary saving. Higher adaptive capacity would enhance their resiliencies to cope with climate shocks. The VGD service providers may enhance intensive nursing to their beneficiaries at grassroots level to engage them into sustainable or realistic income generation activities that may differ from locality to locality or even from household to household (Table 4). The success of the activity can be ensured with proper monitoring.

Table 3: Budget of Chars Livelihood Porgramme (CLP) with project period and area

\begin{tabular}{|l|l|l|l|l|l|l|}
\hline $\begin{array}{l}\text { SL. } \\
\text { No. }\end{array}$ & $\begin{array}{l}\text { CLP's } \\
\text { phase }\end{array}$ & Project period & Project area & \multicolumn{3}{|c|}{ Budget (million) } \\
\cline { 4 - 7 } & $1^{\text {st }}$ & $\begin{array}{l}\text { April 2004 - March } \\
2010\end{array}$ & $\begin{array}{l}\text { Jamalpur, Sirajganj, Bogra } \\
\text { and Gaibanda }\end{array}$ & 50.000 & - & 100.000 \\
\hline \multirow{2}{*}{$2^{\text {nd }}$} & $\begin{array}{l}\text { April 2010 - March } \\
2016\end{array}$ & $\begin{array}{l}\text { Lalmonirhat, Nilphamari, } \\
\text { Rangpur, Tangail, Pabna, } \\
\text { Natore, Rajshahi and Chapai } \\
\text { Nawabganj }\end{array}$ & 70.000 & 8.235 & 140.000 \\
\hline & & & Total & 120.000 & 8.235 & 240.000 \\
\hline
\end{tabular}

Source: Direct visit in CLP HQ at RDA Campus, Bogra.

Full text of this paper can be downloaded online at www.ijssm.org/ \& http://nepjol.info/index.php/IJSSM/issue/archive 


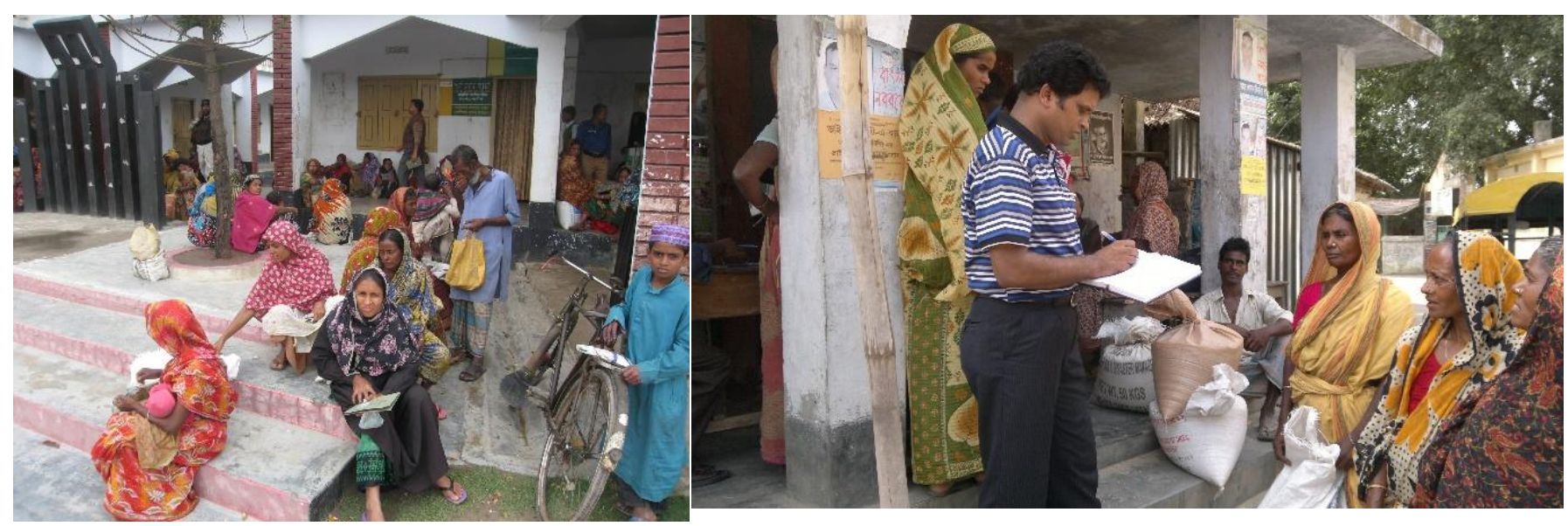

Fig. 7: Some VGD beneficiaries are waiting to receive monthly food grains from local Union Council in Atulia, Shyamnagar, Satkhira district on February 16, 2012 (left), and after receiving monthly food grains in Chala Union, Harirampur, Manikganj District May 29,2012 (right).

Table 4: Options for promoting adaptive capacity of VGD users

\begin{tabular}{|l|l|}
\hline Climate shock & Employment opportunity/income generation policy \\
\hline All types & $\begin{array}{l}\text { Tailoring, cattle or poultry/duck/pigeon rearing, fish culture, production of high value vegetable crops, small } \\
\text { business, handicraft enterprises etc. }\end{array}$ \\
\hline Flood/ water-logging & Production of floating vegetables/horticultural crops, ducks rearing, fish culture \\
\hline Salinity & Sheep and duck rearing (as these are saline tolerant) \\
\hline
\end{tabular}
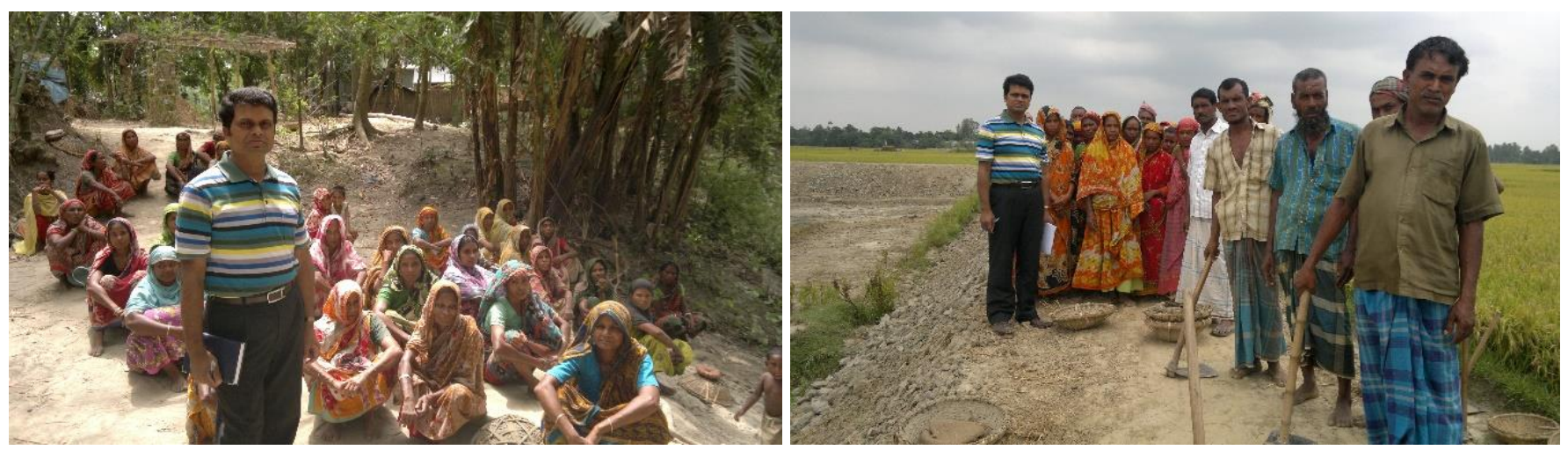

Fig. 8. Photographs show some participants of CFW (left on May 16, 2012) and FFW (right on May 17, 2012) programmes in flood prone Raumari, Kurigram district.

\section{Food-for-Work (FFW) Programme}

It is a very common social safety net programme of GoB. It is utilised for creating the general infrastructures and for the construction/reconstruction of destroyed infrastructure by natural calamities in rural areas (Fig. 8). The main objective of this programme is to generate employment opportunities in slack agricultural dry season in rural areas, to increase the income of rural poor, to take mass operations for the food security in the whole country and to ensure a functional and effective system for poverty alleviation. In this programme, various workfare projects are taken, like digging/re-digging of ponds and irrigation channels, construction/reconstruction of roads and embankments, levelling the sports ground and office yard by soil filling etc. The FFW programme has the following constraints:
- Multi-administrative layers in between the planning and implementation (from central to local levels) create some difficulties. Eventually the work is implemented by the Union Council, however additional interventions from sub-district administration reduces its overall capacity;

- Involvement of higher cost in food distribution system cause the huge loss of public money;

- Weakness in monitoring of programme due to less number of manpower;

\section{Unavailability of soil at the working place}

To achieve CCA from the FFW programme following points can be considered:

- The rural roads and embankments can be elevated and widen enough for reducing the 
risk from flood or tidal surges (and associated water logging or salinity);

- Soil can be collected from dead river or channels (if any) or it is said in the other way that the dead rivers, canals, channels can be excavated which may reduce the risk associated with flood. The excavated soil can be utilized for elevating the roads, embankment, homesteads etc which are crucial to achieve CCA to flood or tidal surges;

- Rural ponds or channels can be excavated/reexcavated deeply for enough harvesting of monsoon or flood water for better agricultural productivity at salinity or drought prone areas. The option can also facilitate the fish culture.

- The programmes can extensively be utilized to maintain local irrigation or drainage channels.

- The programme can be extended to round the year with engaging the FFW participants to the various works in rural Bangladesh.

\section{Rural Employment and Road Maintenance Program (RERMP)}

The RERMP plays significant role for maintaining the rural roads (Fig. 9). Beside the earthen work, the participated women are also responsible to transplant tree seedlings at the road periphery with their proper nursing. However, the RERMP faces the following constraints:

- Salary is very irregular. Sometime the participants get salary after a six month period. Therefore, LGED authority cannot pressurise them for ensuring the target of work;

- The value of daily wage, only Tk. 90/day is insufficient as per inflation occurred over recent years;

- Unavailability of soil mass for maintenance work.

Traditionally, the RERMP reduces the disaster risk as the programme provides employment opportunity for rural poor women. However, CCA neither for household nor for the community is achieved from its operation. Following options can be considered to integrate the CCA interventions with RERMP:

- In addition to repairing, the rural roads can be elevated and widen enough which may reduce the risk due to flood. The beneficiaries can additionally be engaged to repair the embankment/polder in cyclone or flood prone areas;
- The beneficiaries can also be engaged to tree plantation at embankment slope, pond periphery or at barren/khash land with their proper nursing, compost preparation etc. Hence, the programme can be widening to engage more poor women in the locality. The planted trees will not only be appeared as a productive asset (facilitates CCA in various ways) for future but may also serve the environmental protection.

\section{Chars Livelihood Programme (CLP)}

It is considered as the most successful asset transfer based safety net programme (Fig. 10). During primary data collection all the beneficiaries were found happy to participate in this programme. However, it faces the following constraints:

- Communication: Some areas are too distressed and remote from local CLP office that the CLP workers could not reach the working chars easily. Riverbank erosion makes this issue more complex;

- Unavailability of soil: No household would like to provide the soil to elevate the homestead of the others;

- Some beneficiaries break the commitment of CLP's understanding especially after graduation from the programme even within the programme period. For example, selling out the cow which she received from CLP;

- Poor availability of fodder for well nourishing the cattle's they received;

- Salary discrimination: The Diploma Engineers who are working in CLP drawing salary more than the salary of Agricultural graduates like Agriculturists, Veterinarian etc. Therefore, they undermine him or herself to their profession;

- High service charge of Para-Vets due to their insufficient or no salary in CLP.

- Lack of local market system for marketing the CLP-products in time.

The programme can be extended to the chars of other vulnerable flood prone areas of Bangladesh. To fit CLP into more adaptative to climate change, following points can be considered:

- The soil mass (for plinth rising) can be collected from dead rivers or canals (if any) which may reduce the flood risk in the locality;

- The programme can be extended from 18-month to a 24-month period;

- Good market system to timely marketing the CLPproducts. 

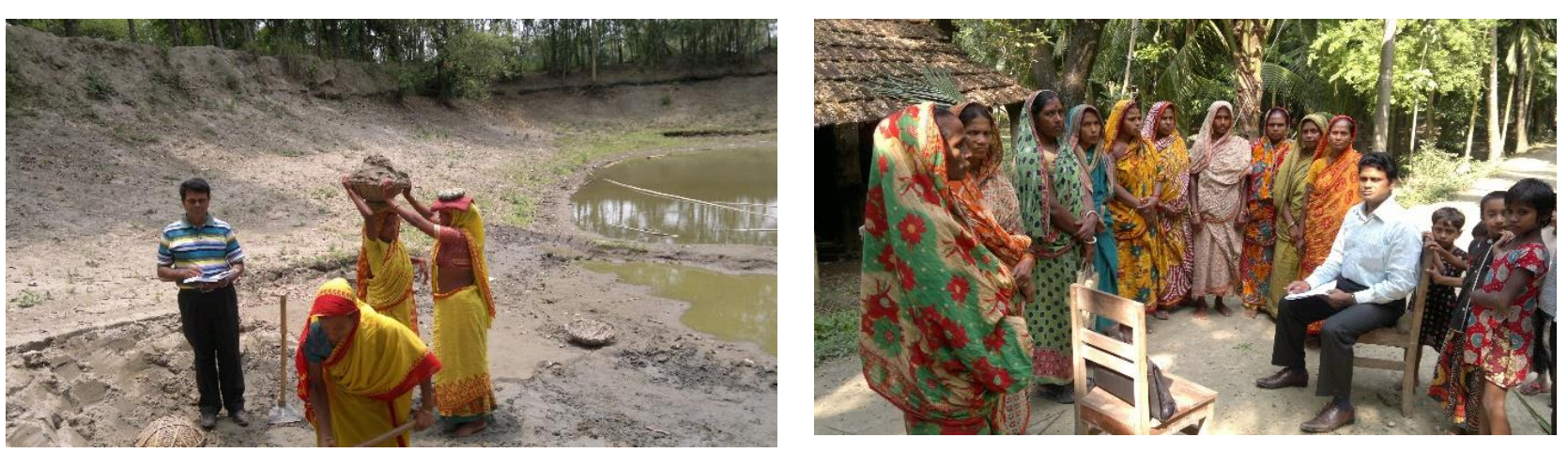

Fig. 9: Some RERMP beneficiaries during road maintenance work in Raumari, Kurigram district on May 17, 2012 (left); and some RERMP beneficiaries were interviewed in Keshabpur, Jessore district on November 12, 2012 (right).
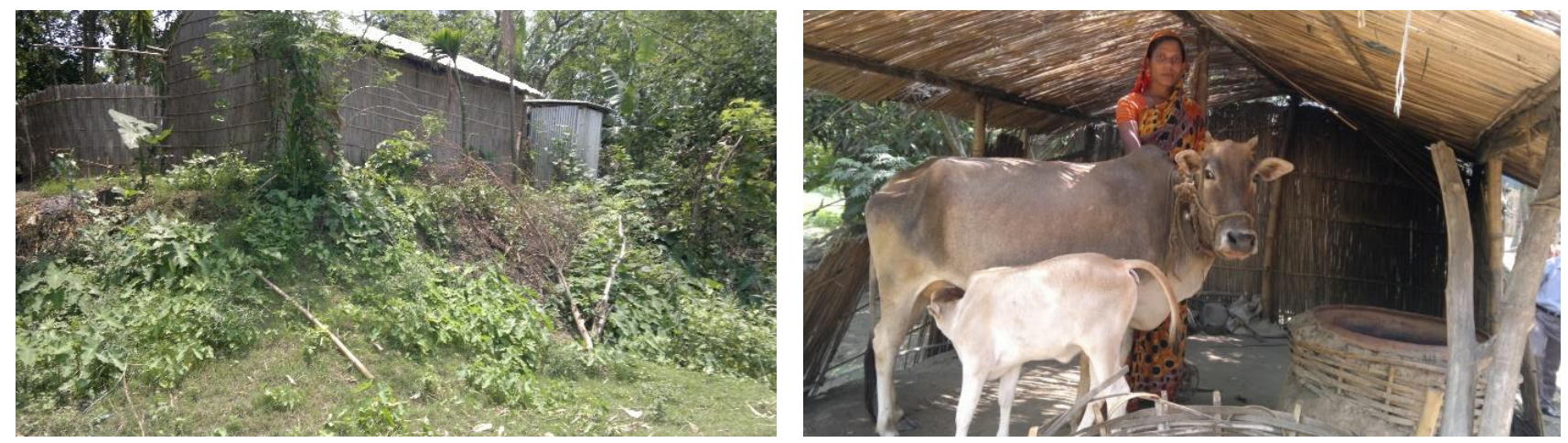

Fig. 10: Photographs show raised plinth for protecting house from regular flood (left); and asset transfer (dairy cow) through CLP in Raumari, Kurigram district on May 16, 2012.

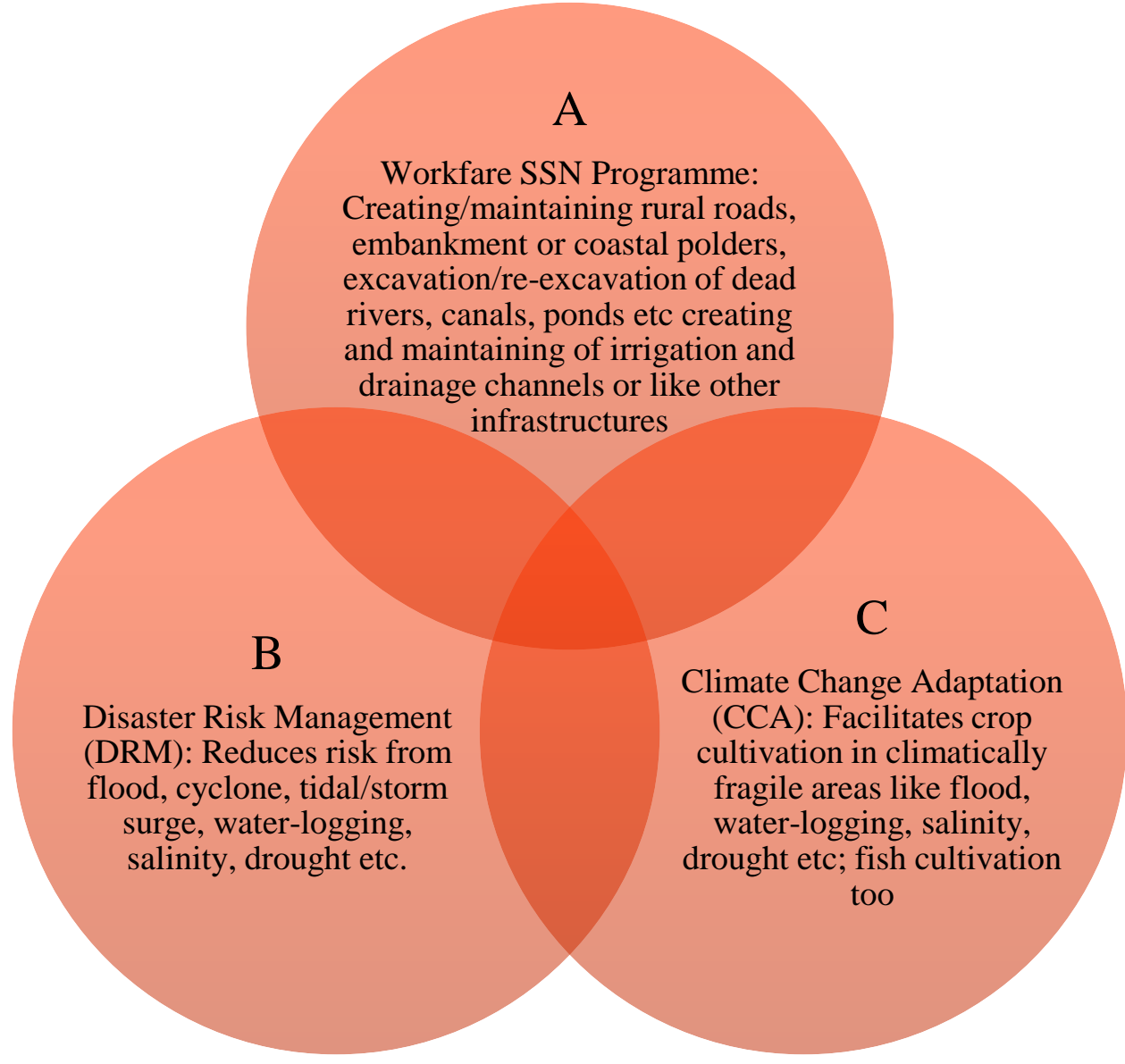

Fig. 11: Integration of workfare SSN programme (A) to DRM (B) and CCA (C) in Bangladesh. 


\section{Discussion}

As the safety net coverage with VGD, RERMP, FFW and CLP is very small as compared to the total household benefitted and spending nationally by the entire package, therefore both spending and household coverage with those specific tools are to be increased if anyone deals the climate change issue. Moreover, the safety net benefit should be oriented solely for the poor households. Therefore, proper care is to be taken for selecting beneficiary households especially for VGD programme as it is one of the unconditional safety net devices in Bangladesh. Unconditional relief aid may create long-term dependence among beneficiaries, destabilize social structures, changes consumption patterns and introduces a rift between beneficiaries and the rest of the population (Bockel et al., 2009) thus safety net services with conditional means can be promoted. As the FFW is a workfare programme so, inclusion of non-poor households in FFW tool is practically difficult due to the social dignity those who want be participated. Therefore workfare programme can be expanded in climate disadvantaged rural areas of Bangladesh.

Safety net service like FFW would facilitate CCA through engaging local unemployed workforce to digging irrigation channels/canals or ponds, de-silting rivers, elevating roads/embankments/polders etc. The avenue can ensure efficient, effective and improve targeting to DRM and CCA, which really serves the poorest of the poor. The said programme can be replicated with many folds to its current state for elevating and widening the road or embankment or coastal polder against flood, tidal surge or salinity; desilting of dead river/canal which would reduce the risk associated with flood or water logging; excavating or reexcavating of pond for harvesting rain or flood water which facilitates agricultural production in saline or drought prone areas, constructing irrigation channels etc. Fig. 11 shows how workfare programme integrate DRM and CCA.

Table 5: Scale-up potentialities of VGD, RERMP, FFW and CLP to climate change adaptation in Bangladesh

\begin{tabular}{|l|l|l|l|}
\hline $\begin{array}{l}\text { Safety net } \\
\text { programme }\end{array}$ & $\begin{array}{l}\text { Major } \\
\text { beneficiary } \\
\text { level }\end{array}$ & $\begin{array}{l}\text { Current } \\
\text { potentiality of } \\
\text { integration }\end{array}$ & Scale-up potentialities to foster climate change adaptation \\
\hline VGD & Household & SSN-DRM & $\begin{array}{l}\text { Enhancing adaptive capacity through promotion of sustainable income } \\
\text { generation and microfinance activities, household saving etc. }\end{array}$ \\
\hline FFW & $\begin{array}{l}\text { Household+ } \\
\text { community/ } \\
\text { state }\end{array}$ & SSN-DRM & $\begin{array}{l}\text { Elevating and widening road or embankment against flood, tidal surge or } \\
\text { salinity; de-siltation of dead river/canal which would reduce the risk associated } \\
\text { with flood or water logging; excavation or re-excavation of pond for harvesting } \\
\text { rain water which facilitates agricultural production in salinity or drought prone } \\
\text { areas etc. }\end{array}$ \\
\hline RERMP & $\begin{array}{l}\text { Household+ } \\
\text { community/ } \\
\text { state }\end{array}$ & SSN-DRM & $\begin{array}{l}\text { Programme extending to maintain the embankment/coastal polder, tree } \\
\text { plantation at pond periphery or at barren/khash land with their proper nursing, } \\
\text { compost preparation etc. }\end{array}$ \\
\hline Household & $\begin{array}{l}\text { SSN-DRM- } \\
\text { (to flood) }\end{array}$ & $\begin{array}{l}\text { Collection of soil mass from dead rivers (if any) for house plinth rising which } \\
\text { would reduce the flood risk; extension the programme to the other flood prone } \\
\text { areas; build good local marketing system to timely market the CLP-products } \\
\text { etc. }\end{array}$ \\
\hline
\end{tabular}

Full text of this paper can be downloaded online at www.ijssm.org/ \& http://nepjol.info/index.php/IJSSM/issue/archive
For developing climate-resilient social protection programmes in rural Bangladesh the FFW programme can be scaled up which allows higher quality benefits, in a way that is faster, more equitable and which comes at a propitious time. This change can occur either vertically or horizontally. A vertical procedure begins with grassroots organizations and is applied at the level of national institutions and policies. A horizontal procedure refers to either a geographical expansion or a replication on a larger scale of households. The participation of the local workforce from the most vulnerable households in FFW programme would ensure their income generation and thus climate change adaptation. This scale-up of FFW's strategy is mostly corresponds with the initiative of Madagascar and Haiti - two most vulnerable countries like Bangladesh where weather-related risks like cyclones, floods and droughts are common which threaten agricultural production and livelihoods just as much as public infrastructure and the national economy (Bockel et al., 2009). The programme can also be implemented to post disaster recovery or in emergency as exemplified in Aceh, Indonesia where the initiative in the form of cash-for-work is proven as successful programme for managing posttsunami by empowering displaced populations to return to their communities; where other reported psychosocial benefits included providing productive activities and giving communities an opportunity to work together (Doocy et al., 2006).

Beside the road maintenance programme, RERMP has also worked for transplanting and nursing tree seedlings on road slopes. The growing trees from those seedlings will be valuable assets in the future - not only for monetary form but also as ecological protection. Therefore proper care is to be required for maintaining or saving those young trees. Nevertheless the government has initiated that plantation programme however long-term maintenance can be ensured through community participation. 
The CLP's stated purpose is to improve the livelihoods, income and food security of extremely poor women, children and men living on island chars in the northwest of Bangladesh. The CLP has achieved significant poverty reduction outcomes in Monga areas. Monga refers to a seasonal period of low employment/income between September and December each year, between the planting and harvest of paddy, which results in hunger for the poorest/most vulnerable members of the population. Monga can be prolonged and intensified due to factors such as the severity of the near annual preceding floods and monsoon. The plinth raising activities, being implemented by the CLP under its comprehensive livelihoods improvement projects for the extremely poor living on the riverine islands, has become an effective model in escaping floods under adverse situations. The plinth-raising programme has been proved to be very effective that not only save char people with properties from floods but also assist them in becoming economically self-reliant amid adverse situations. Habitat protection from recurrent flood makes the CLP fit into climate change adaptation which can be considered as a successful integration of SSN, DRM and CCA. The plinths of 55,000 poorest households were raised under CLP phaseI during 2004-2010 and 65,000 out of 75,000 households so far under phase-II (2010-2016) along with providing assistance to improve livelihoods of 1.9 million extremely poor char people by 2016 (BSS, 2014). The floodwaters could not inundate houses of CLP beneficiaries also having access to sanitation, safe drinking water, healthcare, hygiene, education, microfinance and nutrition for mothers and children under adverse situations.

With the data collected from this study, Table 5 briefly explores the current effectiveness as well as scale-up potentialities of those safety interventions to climate change in socio-economic conditions of Bangladesh.

\section{Conclusion}

The social safety net programmes like Vulnerable Group Development (VGD), Food-For-Work (FFW), Rural Employment and Road Maintenance Program (RERMP) and Chars Livelihood Porgramme (CLP) play important role to uplift the livelihood status of the poor especially distressed women in rural areas of Bangladesh. Although the CLP appeared as a concrete example to integrate climate change adaptation (CCA) for char dwellers in combating recurrent flood in Jamuna and Brahmaputra basins, however, the activities of the other three programmes should go another long way in dealing with climate change shocks viz., flood, cyclone, water logging, salinity and drought. The activities with VGD programme is quite far from the expectation while the FFW and RERMP can serve the purpose if some scale up is assured. The dead or siltedup rivers, canals or ponds and irrigation channels can be excavated or re-excavated by operating major workfare programmes like FFW and the excavated soil can be utilized for creating, maintaining or elevating rural roads, embankment and other infrastructures which are quite crucial for mitigating the flood, storm surge, water logging or salinity issues.

\section{Disclaimer and Acknowledgment}

This paper is based on a study entitled 'Adapting social safety net programs to climate change shocks: issues and options for Bangladesh' financed under the Research Grants Scheme (RGS) of the National Food Policy Capacity Strengthening Programme (NFPCSP). The purpose of the RGS was to assist in improving research and dialogue within civil society so as to inform and enrich the implementation of the National Food Policy. The NFPCSP is implemented by the Food and Agriculture Organization of the United Nations (FAO) and the Food Planning and Monitoring Unit (FPMU), Ministry of Food with the financial support of EU and USAID.

The designation and presentation of material in this publication do not imply the expression of any opinion whatsoever on the part of FAO nor of the NFPCSP, Government of Bangladesh, EU or USAID and reflects the sole opinions and views of the author who is fully responsible for the contents, findings and recommendations of this report.

\section{References}

Awal MA (2013) Social safety net, disaster risk management and climate change adaptation: examining their integration potential in Bangladesh. International Journal of Sociology Study, 1(4): 62-72. www.seipub.org/ijss.

BBS-WB-WFP (2009) Updating poverty maps: Bangladesh poverty maps for 2005, Technical report, August 10. Available from: http://www.wfp.org/sites/default/files/Updating\%20Pove rty\%20Maps \%200f\%20Bangladesh.pdf; accessed on 28 September 2014.

BDS (2006) Social safety nets in Bangladesh: an assessment. Bangladesh Development Series- paper No. 9. South Asia Human Development Unit. The World Bank.

Béné C (2011) Social protection and climate change. IDS Bulletin, 42(6); 67-70.

Bockel L, Thoreux M and Sayagh SD (2009) Resilience of rural communities to climatic acccidents. A need to scale up socio-environmental safety nets (Madagascar, Haiti): Policy Brief. Food and Agriculture Organization (FAO) of the United Nations. Thematic Overview, EASYPol Module 204. Available from: http://www.fao.org/docs/up/easypol/757/rural_cmmnty_r esilience_climatic_accdts_204en.pdf; accessed on November 21, 2014.

BSS (2014) Raised plinth helps six lakh char people escaping flood. Bangladesh Sangbad Sangstha (BSS), National News Agency of Bangladesh. Powered by BSS IT Division \& Bangladesh Online Limited. Available from: http://www.bssnews.net/newsDetails.php?cat=0\&id=434 416\&date=2014-09-03; site accessed on October 7, 2014. 
DDM (2012) Social safety net program. Food For Work (FFW). Department of Disaster Management (DDM), Ministry of Disaster Management and Relief, Government of the Peoples Republic of Bangladesh. Available from: http://www.ddm.gov.bd/socialsafetynet.php; accessed on October 17, 2014.

Doocy S, Gabriel M, Collins S, Robinson C and Stevenson P (2006) Implementing cash for work programmes in posttsunami Aceh: experiences and lessons learned. Disasters, 30(3): 277-296.

GFDRR (2013) Bangladesh's Chars Livelihoods Programme (CLP). Case study. The World Bank Group, Rapid Social Response, Global Facility for Disaster Reduction and Recovery (GFDRR).

HIES (2010) Household Income and Expenditure Survey. Bangladesh Bureau of Statistics, Statistics Division, Ministry of Planning, Government of the People's Republic of Bangladesh.

Jurado GM (2001) An integrated study of selected social safety net policies and programmes in Asia and the Pacific. Paper presented at the regional seminar on strengthening policies and programmes on social safety nets, ESCAP.
LGED (Local Government Engineering Department) (2014) Rural Employment and Road Maintenance Program (RERMP). Local Government Division, Ministry of Local Government Engineering, Rural Development and Cooperatives (LGERD), GoB. Available from: http://www.lged.gov.bd/ProjectHome.aspx?projectID=22 ; accessed on October 17, 2014.

Morshed KAM (2009) Social safety net programmes in Bangladesh. UNDP, Bangladesh.

Paitoonpong S, Abe S and Puopongsakorn N (2008) The meaning of "social safety nets". Journal of Asian Economics, 19(56): 467-473.

UNDP (2010) A 'No-Regrets' risk-based approach to climateproofing of public infrastructure: improved national and sub-national planning for resilience and sustainable growth. www.adaptationlearning.net; accessed on August 8, 2011.

WFP (2014) Vulnerability. World Food Programme (WFP). Available from: http://foodsecurityatlas.org/bgd/country/vulnerability; accessed on 28 September 2014. 


\section{Appendix I}

\section{Vulnerable Group Development (VGD) Programme}

Vulnerable Group Development (VGD), a project implemented by the Government of Bangladesh (GoB) with support from the food aid donors including the World Food Programme (WFP), Australia, Canada, Germany, France and the European Union. It is a most important social safety net programme of the GoB that exclusively targets the ultra poor households. Following the famine of 1974, the project began as a relief programme in November 1975 under the name of Vulnerable Groups Feeding (VGF) with an initial focus on providing food support to destitute women. Under the programme 780,000 distressed women were given wheat and other commodities for the supplementary feeding. The Ministry of Food and Disaster Management, MoFDM (now Ministry of Disaster Management and Relief) instituted food distribution through VGF to address the basic needs of women in extreme poverty. The programme was subsequently oriented towards development and renamed Vulnerable Group Development (VGD) since the mid Eighties. The new objective was to increase self-reliance of the most disadvantaged women. The government however, reintroduced the VGF in 1997 as a separate project. Within the framework of a new 'Strengthening Institutions for Food Assisted Development' (SIFAD) project, the government transferred administration of the VGD from the MoFDM to the Ministry of Women and Children Affairs (MoWCA) in July 1996.

The aim of the VGD programme is to develop the socio-economic condition of the poverty-strike vulnerable women through removing present food-insecurity, financial insolvency and social crisis. The VGD focuses nutritional status of malnourished women and children and enhances self-reliance of ultra poor and food-insecure women in order to ensure their graduation into mainstream development programme. In its design, it also provides training for life-skills and for developing skills needed to undertake income generation activities. Under this programme a $30 \mathrm{~kg}$ of food grains either rice or wheat has been allotted and distributed to each of the distressed households per month free of cost since 1985. The support is provided to each beneficiary for 24 consecutive months hoping that by this time the household will regain the capacity to earn enough to feed its members. On this continuation 217,358 metric tons of food-grains have been allotted and distributed from January 2009 to December 2010 among 621,091 helpless households.

\section{Targeting/Selection criteria of VGD programme:}

i) Women between 18 to 49 year age especially from (a) female-headed household or distressed woman/widow/divorced/abandoned by husband, (b) wife of disabled husband;

ii) Must be physically and mentally sound because disabled ones would qualify for disability allowance;

iii) Irregular income or income below Tk. 300 per capita per month, hence in chronic food insecurity, i.e. members of the households often skips meals due to insufficient food;

iv) Household owning no land, or less than 0.15 acres of land;

v) Households owning no productive asset/income earning asset;

vi) Households survive on casual labour.

\section{Appendix II}

\section{Food-for-Work (FFW) Programme}

The Food-for-Work (FFW) programme was initiated after the devastating flood and subsequent famine of 1974 to provide short term employment for the rural poor. The objectives of the FFW programme are: (i) employment generation for poor mainly in dry agricultural slack season, and (ii) construction, maintenance, reconstruction and development of rural infrastructure. Under this programme both food grains and money as cash are allocated to the Upazilas on the basis of population. The schemes are executed by the Upazila Council (UC) under the supervision of the District Commissioner (DC) through the District Steering Committee. Upazila allocates the rice/wheat/cash money for FFW schemes to the Unions. The Union Councils select and prepares the FFW schemes through their Chairman and Upazila FFW committee scrutinize the schemes and recommends the schemes to the District Co-ordination Committee who approves the schemes. After approval of the schemes the UC executes the schemes as per circular. A participant is benefitted with $2.489 \mathrm{~kg}$ rice or equivalent amount of wheat or cash for transferring one cubic meter soil to a certain distance. Sometimes both food grains and money allocated by the Ministry according to electoral constitution. Accordingly, Cash-for-Work (CFW) is gradually replacing the $F F W$ programme. The programme is implemented by the Department of Disaster Management (DDM) of the Ministry of Disaster Management and Relief, Government of the Peoples Republic of Bangladesh. In addition to FFW, the DDM is also implement some other emergency programmes like Test Relief (TR), execution of Risk Reduction, Relief and Rehabilitation, Vulnerable Group Feeding (VGF), Food Security Enhancement Initiative (FSEI), construction of bridge/culverts and flood/cyclone shelters etc (DDM, 2012).

\section{Targeting/Selection criteria of FFW programme:}

i) The households those who are functionally landless;

ii) Households with lack of productive assets;

iii) Day labour or temporary worker. 


\section{Appendix III}

\section{Rural Employment and Road Maintenance Progamme (RERMP)}

From the experience of FFW programme it was felt that food resource can play a vital role in development of the national economy, and generation of year round employment opportunities for the destitute women is essential for their survival as well as their livelihood improvement. In this back drop, Rural Maintenance Programme (RMP) was started from 1983 that was implemented by various donor agencies like CIDA. However, due to devastating SIDR and flood occurred in 2007 and to increase self-employment, a project proposal was changed and implemented by the Local Government Engineering Department (LGED) financing through GoB because there was no alternative donor agencies. The project name was changed as Rural Employment and Road Maintenance Programme (RERMP) in lieu of RMP. The project was designed with four outputs viz., (i) road maintenance in rural areas, (ii) tree plantation and their nursing, (iii) income generation and training, and (iv) monitoring performance of crew members. Geographically the project covered 4490 Unions of 480 Upazilas of all 64 Districts throughout the country (LGED, 2014).

The major objective of RERMP is to reduce the proportion of the country's rural population below the poverty line through improved access to markets and social services that can be achieved through creating employment for rural destitute women in rural roads maintenance and initiating income generation works to reduce poverty. To achieve the goal, two components namely (i) Rural Maintenance Component (RMC), and (ii) Income Diversification Component (IDC) were implemented under the programme. Under the RMC component about $20 \mathrm{~km}$ of village/market/social institute connecting roads of each Union were maintained by 10 local destitute women on payment of cash wages. As a result, 10 destitute women on every project from a Union got a chance to become self-reliant through working under the project and on the other hand $20 \mathrm{~km}$ of important earthen roads of the Union remained serviceable due to year round maintenance. It is expected that about $75 \%$ of those destitute women would get out of poverty on completion of the project.

Local Government mostly Union Council selects eligible women (rural poor those who have no other source of income) and makes a contract with them for five years. As per contract, women have to work 6 days a week from Saturday to Thursday for 6 hours a day at lower than the local minimum wage. In addition of soil work, tree seedlings are also transplanted by the RERMP beneficiaries at the road periphery. The participated women should wear some selective coloured dress or apron during working time. They are paid 60 percent of their wage (@ Tk. 90 per day) as cash; and bank retains the rest 40 percent of it as savings. 


\section{Appendix IV}

\section{Chars Livelihood Programme (CLP)}

The DFID-funded Chars Livelihood Programme (CLP) is working to improve the livelihoods of extremely poor female headed households living on flood and erosion-prone chars in the Jamuna and Brahmaputra rivers, with the aim of halving extreme poverty in the riverine areas of Bangladesh by 2016. The first phase of the programme (2004-2010, £50 million) has been successfully completed on some chars areas of Jamalpur, Sirajganj, Bogra and Gaibandha districts, and the second phase (2010-2016), which is jointly funding by the DFID ( $£ 70$ million) and AusAid ( $£ 8.235$ million). The second phase’s work is conducting in Lalmonirhat, Nilphamari, Rangpur, Tangail and Pabna districts. The programme was recently (in 2013) extended to the Natore, Rajshahi and Chapai Nawabganj districts. The Government of Bangladesh through ministry of Local Government, Rural Development and Cooperatives (LGRDC) has also extended financial assistances (BDT 10 crore in first phase and BDT 14 crore in second phase) in implementing the CLP to create awareness on socio-economic uplift, health, nutrition, environment, civic rights and disaster management among char dwellers. Under the sponsorship of the Ministry of LGRDC and management through Maxwell Stamp PLC, CLP is being executed by the Rural Development and Cooperatives Division in collaboration with the GO-NGOs in the regions.

The CLP works for constructing flood protected houses and elevating the existing houses to remove the threat of frequent floods due to climate change. A beneficiary household receives a package of physical assets mainly livestock and an 18-month cash stipend worth a total of about BDT 20,000, the equivalent of roughly one-year's household income. The CLP also provides each household with a package of social, livelihood and market development inputs and training worth a further BDT 20,000. The program benefited over 900,000 people during its first phase (2004-2010), and a second phase (2010-2016) is targeting assistance to more than one million people (GFDRR, 2013).

\section{CLP's targeting selection criteria:}

i) Chars' poor those who are asset less, female headed dwellers living their own land since 6 months (at least);

ii) No land except homestead. Households renting homestead land are still eligible;

iii) Having no salaried occupation, only day labourer with less income. Have no loan outstanding from any microfinance or credit program;

iv) Not receiving cash or asset grants from any other asset transfer program. Not benefitted from any other SSN programmes of GO or NGOs;

v) Selected households may not own more than $\mathrm{Tk} 5000$ of productive assets. These are mostly comprised of livestock. No own cow, and the number of either goat or sheep not more than 2 and poultry not more than 10;

vi) Are willing to attend weekly group meetings, participate in a livelihoods programme and show how the asset shall be cared for.

\begin{tabular}{|lll|}
\hline & & \multicolumn{1}{c|}{$\begin{array}{c}\text { Appendix V } \\
\text { Definition of local terms }\end{array}$} \\
Char & $:$ & Small islands and hooks in river deltas which are created due to gradual siltation of riverbed. \\
& & Being low-lying along with adjacent to river, the chars are particularly affected by flooding \\
District & $:$ & Administrative unit of the country in between the Division and Upazila \\
Division & $:$ & Largest administrative unit of government. There are only 7 Divisions in Bangladesh \\
Khash & $:$ & Government or public owned property \\
Sadar Upazila & $:$ & The Upazila which is named with same name of her own district \\
Union Council & $:$ & Also known as Union Parishad; the lowest unit of local government \\
Upazila & $:$ & Previously known as Thana; the lowest tier of formal administration of the country \\
Ward & $:$ & Smallest unit of an Union which comprised of a few village
\end{tabular}

